\title{
Vaginal Cancer pN1 TNM Finding v7
}

National Cancer Institute

\section{Source}

National Cancer Institute. Vaginal Cancer pN1 TNM Finding v7. NCI Thesaurus. Code C89469.

Vaginal cancer with pelvic or ing uinal lymph node metastasis. (from AJCC 7th Ed.) 